\title{
Photosynthetic Responses of Container-grown Illicium L. Taxa to Sun and Shade
}

\author{
Richard T. Olsen, ${ }^{1}$ John M. Ruter, ${ }^{2}$ and Mark W. Rieger ${ }^{3}$ \\ University of Georgia, Coastal Plain Experiment Station, Department of Horticulture, Tifton, GA31793-0748
}

\begin{abstract}
AdDITIONAL INDEX WORDS. Illicium anisatum, Illicium floridanum 'Pebblebrook', Illicium henryi, Illicium lanceolatum, Illicium parviflorum 'Forest Green', star-anise, photoinhibition, carotenoids, SPAD chlorophyll meter

Abstract. Illiciums, or star-anises, have increased in popularity in the nursery and landscape industries. However, confusion exists as to which taxa are tolerant of high light intensities during production and subsequent establishment in the landscape. We investigated the effect of two light intensity treatments, $45 \%$ and $100 \%$ full sunlight, on gas-exchange parameters of five Illicium taxa: Illicium anisatum L., I. floridanum Ellis. 'Pebblebrook', I. henryi Diels., I. lanceolatum A.C. Sm., and I. parviflorum Michx. Ex. Vent. 'Forest Green'. Light-response curves were determined for individual leaves, and mean response parameters calculated. Chlorophyll and total carotenoids were analyzed after extraction in acetone, with total chlorophyll also estimated with a SPAD chlorophyll meter. In general, highest rates of $\mathrm{CO}_{2}$ assimilation $\left(A_{\max }\right)$ and lowest rates of dark respiration $\left(R_{d}\right)$ were found in the $45 \%$ light treatment for all taxa. Both Illicium anisatum and I. floridanum 'Pebblebrook' had substantial reductions in $A_{\max }$ in $100 \%$ light, $94 \%$ and $81 \%$ respectively, compared to plants grown in the $45 \%$ light treatment. Illicium henryi failed to survive the $100 \%$ light treatment. Illicium lanceolatum and I. parviflorum 'Forest Green' were least affected by the $100 \%$ light treatment. Severe photooxidative bleaching was noted and confirmed by SPAD and pigment data, although SPAD readings were a poor predictor of total chlorophyll. For taxa of Illicium in our study, photosynthetic gas-exchange parameters and foliage pigment characteristics were improved in the low light treatment, suggesting optimal growth occurs in shaded conditions.
\end{abstract}

The genus Illicium [Illiciaceae (de Candolle) A.C. Smith] is native to subtropical and temperate regions of southeastern Asia, the Malay archipelago, southeastern United States, Mexico, and the Caribbean (Qi, 1995; Smith, 1947). In the past decade, Illiciums (star-anises) have become increasingly popular ornamentals for landscape use. Ease of propagation, lack of pests and diseases, and durability in the landscape and nursery production have led to their widespread use in the landscape industry (Dirr, 1986; Fantz et al., 1991). Increased demand has prompted many nurseries to seek out new Illicium species and forms to introduce to the nursery trade, often before best cultural practices have been established.

There are conflicting views as to the capability of various Illicium species to survive in full sun. Fantz et al. (1991) suggested that cultivated Illicium species grow well and flower more profusely in full sun than in shade. However, Dirr $(1993 ; 1998)$ observed color loss in foliage of plants when grown in full sun. A distinct yellowing or bleaching of foliage in high light intensities is one symptom of prolonged photoinhibition resulting from photooxidation of plant pigments (Minkov et al., 1999; Xu and Shen, 1999). Photoinhibition is an adaptive process, whereby plants regulate electron transport and energy dissipation in times of excessive excitation of their photosynthetic apparatus (Long et al., 1994). The xanthophyll cycle plays the primary role in thermal energy dissipation, and like other sun-shade acclimations, responds to differences in light intensities. Sun-tolerant or high light tolerant plants exhibit greater concentrations of xanthophyll cycle components, and carotenoids in general, than shade-

Received for publication 8 Jan. 2002. Accepted for publication 22 Aug. 2002. We thank Nancy Hand and Bruce M. Tucker for their technical assistance, Wight Nurseries for propagation of plant materials, and Graco, Harrell's, and The Scotts Company for donation of fertilizers and substrate. This paper is a portion of a thesis submitted by R.T.O. in partial fulfillment of a MS degree. This research was funded in part and supported by state and Hatch funds allocated to the Georgia Agricultural Experiment Station.

${ }^{1}$ Graduate student.

${ }^{2}$ Professor.

${ }^{3}$ Professor, University of Georgia, Department of Horticulture, Athens, GA 30602-7273. adapted species, and likewise, sun leaves contain greater concentrations of these carotenoids than leaves developed in low light on the same plant (Demmig et al., 1987; Demmig-Adams et al., 1989; Demmig-Adams et al., 1995; Demmig-Adams, 1998; Thayer and Björkman, 1990).

The range of light intensity to which a plant can acclimate is determined by an individual species genetic adaptation to the light environment of its native habitat (Boardman, 1977; Pearcy, 1998). Numerous changes in leaf morphology, physiology, and biochemistry are required for acclimation of photosynthesis to various light intensities (Björkman, 1981; Boardman, 1977). Plants native to high light environments are capable of higher photosynthetic rates at high-light intensities than plants from low-light environments. Sun plants are able to increase lightsaturated photosynthetic capacity by increasing protein synthesis, Rubisco activity, and components of the electron-transport chain. Shade plants have inherently low photosynthetic rates, and lack the ability to effectively increase light-saturated photosynthesis (Björkman, 1981).

Illiciums are generally understory shrubs or sub-canopy trees in their native habitats (Gibson, 1992; Nitta and Ohsawa, 1997; White and Thien, 1985), suggesting photosynthetic responses indicative of shade-adapted species. Genetic adaptations for survival in low light intensities may preclude sufficient acclimation by Illiciums when grown in high light intensities. Therefore, our objectives were 1) to quantify the photosynthetic responses of various Illicium taxa to two light intensity treatments, and 2) to determine if photoinhibition and photooxidation occurs in Illiciums grown in high light intensities.

\section{Materials and Methods}

Five Illicium taxa, I. anisatum, I. floridanum 'Pebblebrook', I. henryi, I. lanceolatum, and I. parviflorum 'Forest Green', currently available in the nursery industry were studied. Terminal cuttings were taken from plants growing at the Coastal Plain Experiment Station, Tifton, Ga., on 20 Sept. 1999 and transported to Wight Nurseries, Cairo, Ga., for propagation. Well-rooted liners 
were transported to the Coastal Plain Experiment Station, where they were potted into 2.8-L black plastic containers on 22 May 2000. The substrate consisted of an 8 milled pine bark : 1 sand mix (by volume) amended with dolomitic lime at $1.2 \mathrm{~kg} \cdot \mathrm{m}^{-3}$ and Osmocote Plus 15.0N-4.0P-9.9K (Scotts Co., Marysville, Ohio) applied as a top-dressing with $\mathrm{N}$ at $1.2 \mathrm{~kg} \cdot \mathrm{m}^{-3}$ (20.2 g/container). Plants were randomly placed in one of two light intensity treatments, either $100 \%$ or $45 \%$ ambient photosynthetic photon flux $(P P F)$, in a randomized split-plot design. Plants in $100 \% P P F$ were grown in full sun on a nursery container pad, where average daily maximum ambient $P P F$ was $2110 \mu \mathrm{mol} \cdot \mathrm{m}^{-2} \cdot \mathrm{s}^{-1}$. Plants in $45 \% P P F$ were grown in hoop houses covered in black woven polypropylene fabric where average daily maximum ambient $P P F$ was $1010 \mu \mathrm{mol} \cdot \mathrm{m}^{-2} \cdot \mathrm{s}^{-}$ ${ }^{1}$. Plants were watered as needed.

Beginning in July, plants with one flush of growth hardened under either of the two light treatments were transported to Athens, Ga., for gas-exchange measurements. Plants were placed under the same light treatments in Athens under similar nursery conditions and were brought into the laboratory between 0600 and $0700 \mathrm{HR}$ and allowed to acclimate one hour before measurements began. The container substrate was fully hydrated the night before measurements were performed. Gas-exchange measurements were made using a portable photosynthesis system (LI6200; LI-COR, Lincoln, Nebr.) with a 250-mL leaf chamber. A LED lighting system (QB6200; Quantum Devices, Barneveld, Wis.) attached to the top of the leaf chamber provided light for all measurements. A metal halide light provided supplemental light (between 350 and $700 \mu \mathrm{mol} \cdot \mathrm{m}^{-2} \cdot \mathrm{s}^{-1} P P F$ ) to the remaining plant during the single leaf measurements. Measurements were determined on a fully expanded, mature leaf below the terminal bud on hardened new growth. Measurements were made at 0, 30, 80, 150, 250, 350, 450, 600, 900, 1200, 1500, and $2000 \mu \mathrm{mol} \cdot \mathrm{m}^{-2} \cdot \mathrm{s}^{-1} P P F$. The LED lighting system was calibrated with a quantum radiometer-photometer (LI-189; LI-COR) to attain the desired increment $P P F$ levels. Leaf chamber $\mathrm{CO}_{2}$ concentration was maintained at $365 \pm 10 \mathrm{mg} \cdot \mathrm{L}^{-1}$ and leaf temperatures were between 25 and $30{ }^{\circ} \mathrm{C}$. Because of low relative humidity in the laboratory (40\%) and low photosynthetic rates of Illiciums, leaf chamber relative humidity was low resulting in vapor pressure deficits (VPDs) of $2.0 \pm 0.5 \mathrm{kPa}$.

After the final gas-exchange measurement, the leaf area enclosed in the chamber was measured using a portable area meter (LI3000; LI-COR). A SPAD-502 chlorophyll meter (Minolta, Ramsey, N.J.) was used as a non-destructive tool for estimating leaf chlorophyll (Markwell et al., 1995). Two readings per leaf were taken midway between the leaf mid vein and margin and averaged.

For pigment analysis, one 13-mm leaf disk per leaf was punched out and fresh weight recorded. Leaf disks were stored at $-80^{\circ} \mathrm{C}$ until

Fig. 1.PhotosyntheticlightresponsecurvesforIlliciumanisatum grown in $45 \%(\bigcirc)$ and $100 \%$ (O) of full sunlight. Measurements were made at $365 \pm 10 \mathrm{mg} \cdot \mathrm{L}^{-1} \mathrm{CO}_{2}$, leaf temperatures between 25 and $30^{\circ} \mathrm{C}$, and a vapor pressure deficit of $2.0 \pm 0.5 \mathrm{kPa}$. Negative photosynthetic rates beyond $150 \mu \mathrm{mol} \cdot \mathrm{m}^{-2} \cdot \mathrm{s}^{-1}$ PPF for plants grown in $100 \%$ light precluded comparison of quantum yields $\left(\Phi_{\mathrm{I}}\right)$ and light compensation points $\left(\mathrm{A}_{0}\right)$ between treatments. Data points represent means, with $n=6$. Error bars represent standard errors for the means. pigment analyses were performed. Chlorophylls $a$ and $b$, and total carotenoids were extracted using $80 \%$ acetone following the methods of Bruinsma (1963) with the following exceptions. Because of poor extraction after $24 \mathrm{~h}$ in the dark at $4{ }^{\circ} \mathrm{C}$, leaf disks were homogenized in the acetone solution and extracted for another $24 \mathrm{~h}$ in the dark at room temperature and centrifuged at $2000 \mathrm{~g}_{\mathrm{n}}$ for $2 \mathrm{~min}$. The extinction of the supernatant was measured with a spectrophotometer (Spectronic Genesys 5, Spectronic Instruments, Rochester, New York) at 470, 646, and $663 \mathrm{~nm}$ using the specific absorption coefficients of Lichtenthaler and Wellburn (1983).

Individual photosynthetic-response curves were analyzed by nonlinear regression (SigmaPlot 4.0 for Windows, SPSS, Chicago, Ill.). Cardinal points were calculated from the fitted equations or taken directly as data points. Dark respiration $\left(\mathrm{R}_{\mathrm{d}}\right)$ was measured at $0 \mu \mathrm{mol} \cdot \mathrm{m}^{-2} \cdot \mathrm{s}^{-1} \mathrm{PPF}$ and maximum net $\mathrm{CO}_{2}$ assimilation $\left(\mathrm{A}_{\max }\right)$ was the highest measured rate of net $\mathrm{CO}_{2}$ assimilation $\left(\mathrm{A}_{\text {net }}\right)$ for each plant. The photosynthetic saturation point $\left(\mathrm{A}_{\text {sat }}\right)$ was estimated as $95 \%$ of $A_{\max }$ (Norcini et al., 1991). Apparent quantum yield $\left(\Phi_{\mathrm{I}}\right)$ and light compensation points $\left(\mathrm{A}_{0}\right)$ were calculated by fitting data for $\mathrm{A}_{\text {net }}$ from $P P F<150 \mu \mathrm{mol} \cdot \mathrm{m}^{-2} \cdot \mathrm{s}^{-1}$ to a linear regression, with $P P F$ as the independent variable (Leverenz, 1987), where the slope of the linear regression function equals $\Phi_{\mathrm{I}}$ and the light compensation point is $A_{\text {net }}=0$. Data were analyzed as a split plot design using a general linear model (PROC GLM; SAS version 8.0 for Windows, Cary, N.C.). Light transmittance was the main plot with an error term of block $\times$ light. Taxa was the subplot factor with an error term of block $\times$ taxa + block $\times$ taxa $\times$ light. Standard error of difference between two means (SED) was calculated for all treatment combinations. The relationships between total chlorophyll $\left(\mathrm{Chl}_{\mathrm{tot}}\right)$ and SPAD data were analyzed using regression analysis.

\section{Results}

A significant light $\times$ taxa interaction $(P<0.05)$ occurred for each photosynthetic and pigment parameter except $A_{0}$ and $F_{I}$ (data not shown). The light compensation point $\left(\mathrm{A}_{0}\right)$ and $\Phi_{\mathrm{I}}$ were

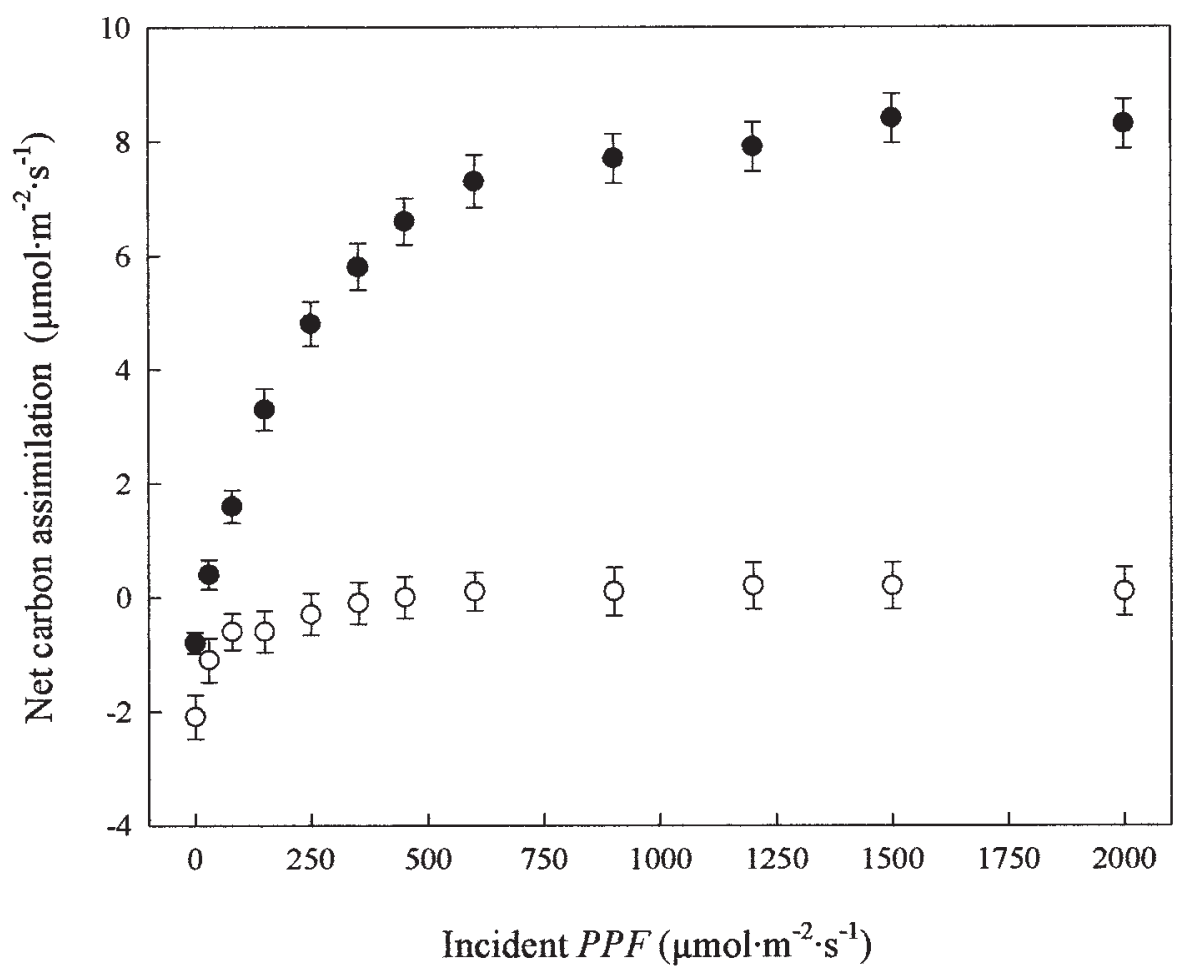


Table 1. Photosynthetic gas-exchange parameters for five Illicium taxa grown in $100 \%$ and $45 \%$ of ambient photosynthetic photon flux. Mean of six replications except $I$. floridanum 'Pebblebrook' in $45 \%$ light where $\mathrm{n}=5$.

\begin{tabular}{|c|c|c|c|c|c|c|}
\hline \multirow[b]{2}{*}{ Taxon } & \multirow{2}{*}{$\begin{array}{c}\text { Light } \\
\text { level }(\%)\end{array}$} & \multicolumn{5}{|c|}{ Photosynthetic gas-exchange parameters ${ }^{z}$} \\
\hline & & \multicolumn{3}{|c|}{$\left(\mu \mathrm{mol} \mathrm{CO} / \mathrm{m}^{-2} \cdot \mathrm{s}^{-1}\right)$} & \multicolumn{2}{|c|}{$\left(\mu \mathrm{mol}\right.$ photons $\left./ \mathrm{m}^{-2} \cdot \mathrm{s}^{-1}\right)$} \\
\hline & 45 & 8.39 & 7.97 & -0.78 & 22.2 & 0.0261 \\
\hline \multirow[t]{2}{*}{ I. floridanum 'Pebblebrook' } & 100 & 1.55 & 1.47 & -1.19 & --- & --- \\
\hline & 45 & 7.48 & 7.11 & -1.33 & 56.6 & 0.0202 \\
\hline \multirow[t]{2}{*}{ I. lanceolatum } & 100 & 3.78 & 3.59 & -2.07 & 81.9 & 0.0197 \\
\hline & 45 & 5.67 & 5.38 & -1.81 & 55.9 & 0.0295 \\
\hline \multirow[t]{2}{*}{ I. parviflorum 'Forest Green' } & 100 & 9.07 & 8.62 & -1.20 & 29.4 & 0.0330 \\
\hline & 45 & 10.90 & 10.37 & -0.61 & 16.1 & 0.0327 \\
\hline \multicolumn{7}{|l|}{ SED $^{w}$} \\
\hline
\end{tabular}

${ }^{\mathrm{z}}$ Maximum net leaf $\mathrm{CO}_{2}$ assimilation $=\mathrm{A}_{\max }$ ), net leaf $\mathrm{CO}_{2}$ assimilation at light saturation $=\mathrm{A}_{\text {sat }}$, dark respiration $=\mathrm{R}_{\mathrm{d}}$, light compensation point $=\mathrm{A}_{0}$, and apparent quantum yield of leaf photosynthesis $=\Phi_{\mathrm{I}}$.

${ }^{\mathrm{y}} \mathrm{A}_{0}$ and $\mathrm{F}_{\mathrm{I}}$ were not calculated for I. anisatum and I. floridanum 'Pebblebrook' grown in the $100 \%$ light treatments due to severe inhibition of photosynthesis at the low light levels used for calculation of these parameters.

${ }^{x}$ No I. henryi survived the $100 \%$ light treatment.

${ }^{\text {w }}$ Standard error of difference between two means (SED). No significant interaction or light effect was observed for $\mathrm{A}_{0}$ and $\Phi_{\mathrm{I}}$. A significant $(P<$ 0.001 ) taxa effect occurred for both parameters. SED for taxa comparison are 6.5 and 0.00265 for $\mathrm{A}_{0}$ and $\Phi_{\mathrm{I}}$, respectively.

not calculated for I. anisatum and I. floridanum 'Pebblebrook' grown in the $100 \%$ light level treatment because of negative photosynthetic rates at the low light levels $\left(<150 \mu \mathrm{mol} \cdot \mathrm{m}^{-2} \cdot \mathrm{s}^{-1}\right.$ $P P F)$ used for calculation of these response variables, as shown in Fig. 1. Light had no effect on $\Phi_{\mathrm{I}}$ and $\mathrm{A}_{0}$; however, there was a significant $(P<0.001)$ taxa effect for both parameters (data not shown).

In general, the highest $\mathrm{A}_{\max }$ values for each taxa studied occurred in the $45 \%$ light treatment (Table 1). Although $\mathrm{A}_{\text {sat }}$ varied by taxa and light treatment, saturation of photosynthesis occurred at similar intercellular $\mathrm{CO}_{2}\left(\mathrm{C}_{\mathrm{i}}\right)$ levels, between 200 and $230 \mathrm{mg} \cdot \mathrm{L}^{-1}$ (data not shown). However, plants of I. anisatum and I. floridanum 'Pebblebrook' in 100\% light that exhibited inhib- ited photosynthetic rates, saturated at higher $\mathrm{C}_{\mathrm{i}}$ levels, between 300 and $350 \mathrm{mg} \cdot \mathrm{L}^{-1}$ (data not shown).

No plants of $I$. henryi survived the $100 \%$ light treatment, and I. henryi plants in the $45 \%$ light treatment had low $\mathrm{A}_{\max }, \mathrm{A}_{\text {sat }}$, and $\Phi_{\text {I }}$ relative to the other taxa in the $45 \%$ light treatment (Table 1). Dark respiration $\left(R_{d}\right)$ was also low, and thus the low $\Phi_{I}$ was the main contributing factor to the high $\mathrm{A}_{0}$ for shade plants of I. henryi.

Illicium anisatum and I. floridanum 'Pebblebrook' had similar responses to light treatments (Table 1). For both species in the $100 \%$ light treatment, $\mathrm{A}_{\max }$ and $\mathrm{A}_{\mathrm{sat}}$ were greatly reduced compared to rates in the $45 \%$ light treatment. Maximum rates of net $\mathrm{CO}_{2}$ assimilation $\left(\mathrm{A}_{\max }\right)$ decreased by $94 \%$ and $81 \%$ for I. anisatum and I. floridanum 'Pebblebrook', respectively. Dark respiration rates varied between

Table 2. Leaf pigment data for five Illicium taxa grown in $100 \%$ and $45 \%$ ambient photosynthetic photon flux. Mean of six replications except $I$. floridanum 'Pebblebrook' in $45 \%$ light where $\mathrm{n}=5$.

\begin{tabular}{|c|c|c|c|c|c|c|c|}
\hline Taxon & $\begin{array}{c}\text { Light } \\
\text { level }(\%)\end{array}$ & \multicolumn{6}{|c|}{ Leaf pigment $\operatorname{concn}^{\mathrm{z}}\left(\mu \mathrm{g} \cdot \mathrm{cm}^{-2}\right)$} \\
\hline I. anisatum & 100 & 47.0 & 17.9 & 29.1 & 0.61 & 9.8 & 17.5 \\
\hline \multirow[t]{2}{*}{ I. floridanum 'Pebblebrook' } & 100 & 83.8 & 31.9 & 51.9 & 0.61 & 17.3 & 27.8 \\
\hline & 45 & 56.8 & 22.2 & 34.6 & 0.64 & 7.6 & 59.8 \\
\hline I. henryi ${ }^{\mathrm{y}}$ & 100 & --- & --- & --- & --- & --- & --- \\
\hline I. lanceolatum & 45 & 55.3 & 25.6 & 29.7 & 0.85 & 4.2 & 58.9 \\
\hline \multirow[t]{2}{*}{ I. parviflorum 'Forest Green' } & 100 & 38.3 & 14.5 & 23.8 & 0.60 & 4.0 & 54.8 \\
\hline & 45 & 35.5 & 13.0 & 22.5 & 0.58 & 2.7 & 57.8 \\
\hline \multicolumn{8}{|l|}{$\mathrm{SED}^{\mathrm{w}}$} \\
\hline \multicolumn{2}{|c|}{ Between light treatments, same taxa } & 8.1 & 3.5 & 4.7 & 0.04 & 1.7 & 8.6 \\
\hline Between taxa, same light $t$ & nent & 8.2 & 3.6 & 4.8 & 0.04 & 1.8 & 4.2 \\
\hline
\end{tabular}

${ }^{\mathrm{z}}$ Abbreviations: total chlorophyll $\left(\mathrm{Chl}_{\text {tot }}\right)$, chlorophyll $a(\mathrm{Chl} a)$, chlorophyll $b(\mathrm{Chl} b)$, chlorophyll $a: b$ ratio (Chl $\left.a: b\right)$, total xanthophylls and carotenoids $\left(\mathrm{Chl}_{\mathrm{x}+\mathrm{c}}\right)$, SPAD-502 chlorophyll meter reading (SPAD).

${ }^{\mathrm{y}}$ No Illicium henryi survived the $100 \%$ light treatment.

${ }^{\mathrm{w}} \mathrm{S}$ tandard error of difference between two means (SED). 
species, from $-2.11 \pm 0.36$ and $-1.19 \pm 0.17 \mu \mathrm{mol} \cdot \mathrm{m}^{-2} \cdot \mathrm{s}^{-1}$, for $I$. anisatum and I. floridanum 'Pebblebrook', respectively. Both species had comparable rates of $\mathrm{A}_{\max }$ and $\mathrm{A}_{\text {sat }}$ in the $45 \%$ light treatment. Illicium anisatum's high $\Phi_{\mathrm{I}}$ and low $\mathrm{R}_{\mathrm{d}}$ contributed to a low $\mathrm{A}_{0}$. Illicium floridanum 'Pebblebrook's low $\Phi_{\mathrm{I}}$ and high $\mathrm{R}_{\mathrm{d}}$ resulted in a high $\mathrm{A}_{0}$.

Illicium lanceolatum and I. parviflorum 'Forest Green' can also be grouped together according to their similar responses to the light treatments, even though photosynthetic rates differed (Table 1). Maximum rates of net $\mathrm{CO}_{2}$ assimilation $\left(\mathrm{A}_{\max }\right)$ and $\mathrm{A}_{\mathrm{sat}}$ decreased by $33 \%$ and $17 \%$ for I. lanceolatum and I. parviflorum 'Forest Green', respectively, in the $100 \%$ light treatment compared with the $45 \%$ light treatment. A low $\Phi_{\mathrm{I}}$ and high $\mathrm{R}_{\mathrm{d}}$ led to a high $\mathrm{A}_{0}$ for $I$. lanceolatum in the $100 \%$ light treatment. In the $45 \%$ light treatment $\Phi_{\mathrm{I}}$ was higher and $\mathrm{R}_{\mathrm{d}}$ remained high, leading to a relatively high $\mathrm{A}_{0}$ for I. lanceolatum. Illicium parviflorum 'Forest Green' maintained a high $\Phi_{\mathrm{I}}$ in both light treatments. Increased $\mathrm{R}_{\mathrm{d}}$ resulted in a higher $\mathrm{A}_{0}$ for I. parviflorum 'Forest Green' in the $100 \%$ light treatment. Leaves of I.parviflorum 'Forest Green' in $100 \%$ PPF had vertically disposed leaves, much more so than on leaves of plants in $45 \% \mathrm{PPF}$. This response was not observed in the other Illicium taxa.

No consistent pattern was observed in $\mathrm{Chl}_{\text {tot }}$ due to light treatments (Table 2), which is not uncommon in light intensity studies (Pearcy, 1998). Chlorophyll $a: b$ ratios were low and remained within a narrow range of 0.58 to 0.87 between light treatments and taxa (Table 2). In general, carotenoid levels increased in the $100 \%$ light treatment for all taxa. Illicium anisatum and I. floridanum 'Pebblebrook' demonstrated the greatest percent increases in carotenoid concentrations of $326 \%$ and $127 \%$, respectively. Illicium lanceolatum and I. parviflorum 'Forest Green' showed the smallest increases of $78 \%$ and $42 \%$, respectively. In the $45 \%$ light treatment, plants of I. floridanum 'Pebblebrook' and I. henryi had higher levels of carotenoids relative to other taxa. Total chlorophyll concentrations were poorly fitted to SPAD readings $\left(R^{2}=0.03\right)$, but did confirm visual observations of foliage color during the experiment. Plants of I. anisatum and I. floridanum 'Pebblebrook' in the 100\% light treatment appeared bleached and yellow, as shown in their low SPAD readings and high carotenoid levels (Table 2). Severe bleaching was observed on plants of $I$. henryi subsequent to plant death in the $100 \%$ light treatment. SPAD readings for I. lanceolatum were lower in the $100 \%$ treatment than in the $45 \%$ treatment. Light treatment did not influence SPAD readings of $I$. parviflorum 'Forest Green'.

\section{Discussion}

Maximum rates of net $\mathrm{CO}_{2}$ assimilation $\left(\mathrm{A}_{\max }\right)$ observed for Illicium taxa in this study are similar to rates reported for broadleaf evergreen species adapted to low light environments (Andersen et al., 1991a, 1991b; Langenheim et al., 1984) although these rates may have been somewhat attenuated due to the higher than expected VPD in the leaf chamber during gas-exchange measurements. Low rates of $\mathrm{CO}_{2}$ assimilation in shade-adapted plants are not attributed to differences in rates of stomatal conductance between sun and shade plants (Björkman, 1981). The inability of shade-adapted species to increase rates of net $\mathrm{CO}_{2}$ assimilation when grown in high light is also not attributable to stomatal limitations. Langenheim et al. (1984) showed that for several species of tropical shade-tolerant evergreens, stomatal conductance decreased in high light; however, $\mathrm{C}_{\mathrm{i}}$ remained similar between light treatments. They suggested that low photosynthetic capacity, rather than low stomatal conductance, resulted in a lack of photosynthetic acclimation to increases in $P P F$. A similar trend was observed for Aucuba japonica 'Variegata', a shadeadapted, broad-leaved evergreen native to temperate Asia, in a container-production study in Florida (Andersen et al., 1991a). Saturation of Illicium taxa in our study occurred from 200 to 230 $\mathrm{mg} \cdot \mathrm{L}^{-1} \mathrm{C}_{\mathrm{i}}$, regardless of light treatment and taxa. This $\mathrm{C}_{\mathrm{i}}$ level for $\mathrm{A}_{\text {sat }}$ implies that the inability of Illicium taxa in this study to increase $\mathrm{A}_{\max }$ when grown at $100 \%$ light is due to inherently low photosynthetic capacities. The failure to increase rates of photosynthesis with increasing light is a direct result of an inability to increase rate-limiting steps of photosynthesis, including Rubisco synthesis and activation (Seemann, 1989) and electron transport (Bjorkman, 1981; Boardmann, 1977).

Excess light, or light stress, is induced when the ratio of photon flux density to photosynthesis is high (Demmig-Adams and Adams, 1992). Thus, for plant species unable to increase $A_{\max }$ with increases in light, long-term exposure to high light will result in prolonged light stress and photoinhibition, the decrease in photosynthetic activity induced by light in excess of that used in photosynthesis (Xu and Shen, 1999). Substantial decreases in photosynthetic activity were observed for most Illicium taxa in the $100 \%$ light treatment. The smallest decline in $\mathrm{A}_{\max }(17 \%)$ was observed with I. parviflorum 'Forest Green'. In addition, $\mathrm{F}_{\mathrm{I}}$, a measure of photosynthetic efficiency which often declines with light stress (Long et al., 1994; Pearcy, 1998), remained unchanged between light treatments for I. parviflorum 'Forest Green', suggesting this taxon was able to avoid light stress. The vertical leaf orientation of plants in $100 \%$ light may have effectively decreased the absorption of incident light, possibly to levels observed by plants in the $45 \%$ light treatment, a strategy used by mangrove species to avoid high levels of incident $P P F$ (Lovelock and Clough, 1992), and implied here by the low $\mathrm{A}_{0}$ values plants grown in $100 \%$ light. Although photosynthesis appeared to acclimate to high light for I. parviflorum 'Forest Green', $\mathrm{R}_{\mathrm{d}}$ increased by $97 \%$ in high light, suggesting increased maintenance costs, perhaps from increased protein turnover in high light (Pearcy, 1998). Increased respiration, without an increase in photosynthesis, would have a negative effect on carbon-use efficiency, suggesting optimal growth for $I$. parviflorum 'Forest Green' would occur in light intensities below $100 \%$ light.

The decline in $\mathrm{A}_{\max }$ for I. lanceolatum in the $100 \%$ light treatment was accompanied by a decline in $\Phi_{\mathrm{I}}$ and increased levels of carotenoids. Declines in photosynthesis due to photoinhibition are the result of declines in photosynthetic efficiency, as energy from absorbed quanta is dissipated as heat instead of being used in photochemistry (Long et al., 1994). The xanthophyll cycle is recognized as the major thermal energy dissipation pathway in plants (Long et al., 1994; Xu and Shen, 1999) with increases in total carotenoid concentrations in high PPF due to increases in xanthophyll cycle components (Demmig et al., 1987; Demmig-Adams, 1998; Demmig-Adams et al., 1989; Demmig-Adams et al., 1995; Thayer and Bjorkman, 1990). However, shade-adapted species have a low capacity for xanthophyll cycle mediated energy dissipation compared to sun-adapted species (Demmig-Adams et al., 1995), and when combined with their low rates of photosynthesis, predispose shade-adapted plants to photoin-hibition. Prolonged inhibition in the transfer of excitation energy from excited chlorophyll to the quinnone acceptors results in triplet chlorophyll formation, which reacts with oxygen to produce singlet oxygen and oxygen radicals. Both are active oxygen species capable of damaging proteins, pigments, and 
thylakoid membranes, which results in photooxidative bleaching (Minkov et al., 1999). The responses of I. anisatum and I. floridanum 'Pebblebrook' to $100 \%$ light is indicative of this type of severe damage to the photosynthetic apparatus. Both species exhibited significant decreases in $\mathrm{A}_{\max }$, and $\Phi_{\mathrm{I}}$ decreased to immeasurable rates. Intercellular $\mathrm{CO}_{2}$ levels remained high, decreasing little below ambient $\mathrm{CO}_{2}$ levels, indicating a reduced demand for carbon. A more significant decrease in $\mathrm{C}_{\mathrm{i}}$ would be expected if the decrease in $\mathrm{A}_{\max }$ was due to any decreases in stomatal conductance from the higher than ideal VPD in the leaf chambers during gas-exchange measurements. The observed decreases, however, can occur if there is a massive accumulation of damaged reaction centers, which instead of transferring absorbed light energy for use in carbon assimilation, dissipate absorbed energy as heat (Pearcy, 1998).

The SPAD readings and increases in carotenoids concentrations confirmed visual observations of photooxidative bleaching in leaves of $100 \%$ light grown I. anisatum and I. floridanum 'Pebblebrook' plants. However, the chlorophyll pigment data are inconsistent with regard to expected chlorophyll losses from photooxidation. Illicium anisatum had substantially lower $\mathrm{Chl}_{\text {tot }}$ combined with increased carotenoids in $100 \% P P F$, corroborating evidence for photooxidative bleaching. Illicium floridanum 'Pebblebrook', on the other hand, had high $\mathrm{Chl}_{\text {tot }}$, but low SPAD readings in $100 \%$ light. These inconsistencies led to the poor relationship between SPAD and chlorophyll data. Campbell et al. (1990) showed that growing conditions affect the relationship of SPAD readings to total chlorophyll, due in part to differences in leaf morphology. In a recent study, SPAD readings were highly correlated to total chlorophyll levels and visual observations of color for greenhouse grown st. augustinegrass, but correlated poorly in field grown plants due to a lack of uniformity in ontogenetic age of the samples and sampling error (Rodriguez and Miller, 2000). Re-analysis of our data, attempting to account for the above possibilities, failed to improve the relationship of SPAD readings to chlorophyll data. The low Chl $a: b$ ratios observed for Illicium taxa in this study are substantially lower than published ratios for other broad-leaved evergreen taxa (Demmig-Adams, 1998; Thompson et al., 1992) and $\mathrm{C}_{3}$ plants in general (Demmig-Adams, 1998). These low ratios may be indicative of poor extraction of chlorophyll by acetone in Illicium leaves, and would also confound the relationship of SPAD readings to chlorophyll pigment data.

Failure of I. henyri to survive the $100 \%$ light treatment represents the most severe example of the inability to acclimate to high light by a shade-adapted species. Plants were visibly bleached and necrotic within 1 month, and all were dead by the end of the second month. In a light intensity study with Rhododendron x 'Pink Ruffles', Andersen et al. (1991b) suggested that photoinhibition and photooxidation damage was responsible for reduced growth and chlorosis of plants in $100 \%$ sunlight. They concluded Rhododendron X'Pink Ruffles' required partial shade, with no amount of acclimation preventing chlorosis and dieback when plants were transplanted from various light intensities into full sun. In a similar study using the broad-leaved evergreen Aucuba japonica 'Variegata', plants grown in 100\% sun became chlorotic and necrotic in just $30 \mathrm{~d}$, with complete defoliation occurring by the end of the summer (Andersen et al., 1991a). Aucuba japonica 'Variegata' was classified as a shade obligate, where optimum plant growth occurs in light intensities of less than $47 \%$ of full sun. Although I. henryi was the only taxon in our study that failed to survive the $100 \%$ light treatment, it is highly probable that I. anisatum and I. floridanum 'Pebblebrook' would fail to survive the rest of the growing season in full sun, given their poor acclimation by mid-season. High temperature and excess light often occur together in nature, where heat induced disruption of the thylakoid membrane can impair the ability of the leaf to dissipate excess absorbed light (Al-Khatib and Paulsen, 1989). Plants grown in $100 \%$ of full sunlight would have been exposed to a combination of high light and high temperatures during the growing season. Our experimental design precluded the partitioning of damage between excess light absorption and differences in foliage temperature expected between the $45 \%$ and $100 \%$ light treatments.

The photosynthetic responses of Illicium taxa reflected the light levels prevalent in their native habitats. Illiciums are generally understory shrubs or sub-canopy trees in their native habitats (Gibson, 1992; Nitta and Ohsawa, 1997; White and Thien, 1985) where light levels $(P P F)$ of less than full sun are expected. In our study, optimal rates of photosynthesis occurred in $45 \% P P F$, with significant decreases occurring for most taxa when grown at $100 \%$ PPF. Photoinhibitory responses, varying in severity, were documented for all taxa, suggesting optimal growth in containernursery production should occur in light levels below $100 \% P P F$. Most nurseries propagate Illiciums by stem cuttings, or rarely by seed (Olsen and Ruter, 2001). Although several cultivars of $I$. floridanum and parviflorum are in the nursery trade (Dirr, 1998), I. henryi is most likely represented by a single clone from its original introduction into the United States. Illicium henryi was introduced by Woodlanders, Inc., Aiken S.C., as cuttings from a specimen growing at The Sir Harold Hillier Gardens and Arboretum, Romsey, Hampshire, U.K. (Bob McCartney, personal communication.). Illicium lanceolatum was introduced by $\mathrm{Ca}$ mellia Forest Nursery, Chapel Hill, N.C. as plants grown from seed from the Hangzhou Botanic Garden, Hangzhou, China in 1985 (Clifford Parks, personal communication). The clone of $I$. lanceolatum in our study, although perhaps not representing the species as a whole, out performed the taxonomically and morphologically similar I. henryi in sun and shade, and may be a substitute for the more popularly grown $I$. henryi.

\section{Literature Cited}

Al-Khatib, K. and G.M. Paulsen. 1989. Enhancement of thermal injury to photosynthesis in wheat plants and thylakoids by high light intensity. Plant Physiol. 90:1041-1048.

Andersen, P.C., G.W. Knox, and J.G. Norcini. 1991a. Light intensity influences growth and leaf physiology of Aucuba japonica 'Variegata'. HortScience 26:1485-1488.

Andersen, P.C., J.G. Norcini, and G.W. Knox. 1991b. Influence of irradiance on leaf physiology and plant growth characteristics of Rhododendron X 'Pink Ruffles'. J. Amer. Soc. Hort. Sci. 116:881-887. Björkman, O. 1981. Responses to different quantum flux densities, p. 57-107. In: O.L. Lange, P. S. Nobel, C. B. Osmond, and H. Zeigler (eds.). Encyclopedia of Plant Physiology (New Series). vol. 12A. Springer-Verlag, Berlin.

Boardman, N.K. 1977. Comparative photosynthesis of sun and shade plants. Annu. Rev. Plant Physiol. 28:355-377.

Bruinsma, J. 1963. The quantative analysis of chlorophylls $a$ and $b$ in plant extracts. Photochem. Photobiol. 2:241-249.

Campbell, R.J., K.N. Mobley, R.P. Marini, and D.G. Pfeiffer. 1990. Growing conditions alter the relationship between SPAD-501 values and apple leaf chlorophyll. HortScience 25:330-331.

Demmig, B., K. Winter, A. Kruger, and F.-C. Czygan. 1987. Photoinhibition and zeaxanthin formation in intact leaves. A possible role of the xanthophyll cycle in the dissipation of excess light energy. Plant Physiol. 84:218-224. 
Demmig-Adams, B. 1998. Survey of thermal energy dissipation and pigment composition in sun and shade leaves. Plant Cell Physiol. 39:474-482.

Demmig-Adams, B. and W.W. Adams, III. 1992. Photoprotection and other responses of plants to high light stress. Annu. Rev. Plant Physiol. Plant Mol. Biol. 43:599-626.

Demmig-Adams, B., W.W. Adams, III., B.A. Logan, and A.S. Verhoeven. 1995. Xanthophyll cycle-dependent energy dissipation and flexible photosystem II efficiency in plants acclimated to light stress. Austral. J. Plant Physiol. 22:249-260.

Demmig-Adams, B., K. Winter, E. Winkelmann, A. Kruger, and F.-C. Czygan. 1989. Photosynthetic characteristics and the ratios of chlorophyll, $\beta$-carotene, and the components of the xanthophyll cycle upon a sudden increase in growth light regime in several plant species. Bot. Acta 102:319-325.

Dirr, M.A. 1986. Hardy Illicium species display commendable attributes. Amer. Nurseryman 163(1):92-94,98,100.

Dirr, M.A. 1993. Illicium, anise: various species and cultivars are made for the shade, and they flourish across zones 6-9. Nursery Manager 9(3):34,36,38.

Dirr, M.A. 1998. Manual of woody landscape plants. 5th ed. Stipes Publ., Champaign, Ill.

Fantz,P.R., J.C. Raulston, and R. McCartney. 1991. Illicium evaluations in the NCSU Arboretum. Proc. South. Nursery Assn. Res. Conf. 36:300-304.

Gibson, D.J. 1992. Vegetation-environment relationships in a southern mixed hardwood forest. Castanea 57:174-189.

Langenheim, J.H., C.B. Osmond, A. Brooks, and P.J. Ferrar. 1984. Photosynthetic responses to light in seedlings of selected Amazonian and Australian rainforest tree species. Oecologia 63:215-224.

Leverenz, J.W. 1987. Chlorophyll content and the light response curve of shade-adapted conifer needles. Physiol. Plant. 71:20-29.

Lichtenthaler, H.K. and A.R. Wellburn. 1983. Determinations of total carotenoids and chlorophylls $a$ and $b$ of leaf extracts in different solvents. Biochemical Soc. Trans. 11:591-592.

Long, S.P., S. Humphries, and P.G. Falkowski. 1994. Photoinhibition of photosynthesis in nature. Annu. Rev. Plant Physiol. Plant Mol. Biol. 45:633-662.

Lovelock, C.E. and B.F. Clough. 1992. Influence of solar radiation and leaf angle on leaf xanthophylls concentrations in mangroves. Oecologia 91:518-525.
Markwell, J., J.C. Osterman, and J.L. Mitchell. 1995. Calibration of the Minolta SPAD-502 leaf chlorophyll meter. Photosyn. Res. 46:467472.

Minkov, I.N., G.T. Jahoubjan, I.D. Denev, and V.T. Toneva. 1999. Photooxidative stress in higher plants, p. 499-525. In: M. Pessaraki (ed.). Handbook of plant and crop stress. 2nd ed. Marcel Dekker, New York.

Nitta, I. and M. Ohsawa. 1997. Leaf dynamics and shoot phenology of eleven warm-temperate evergreen broad-leaved trees near their northern limit in central Japan. Plant Ecol. 130:71-88.

Norcini, J.G., G.W. Knox, and P.C. Andersen. 1991. Leaf gas exchange of eastern redbud (Cercis canadensis L.) grown under sun and shade. J. Environ. Hort. 9:215-218.

Olsen, R.T. and J.M. Ruter. 2001. Preliminary study shows that cold, moist stratification increases germination of 2 native Illicium species. Native Plants J. 2:79-83.

Pearcy, R.W. 1998. Acclimation to sun and shade, p. 250-263. In: A.S. Raghavendra (ed.). Photosynthesis: A comprehensive treatise. Cambridge Press, Cambridge.

Qi, L. 1995. The geographical distribution of the family Illiciaceae. J. Trop. Subtrop. Bot. 3:1-11.

Rodriguez, I.R. and G. L. Miller. 2000. Using a chlorophyll meter to determine the chlorophyll concentration, nitrogen concentration, and visual quality of st. augustinegrass. HortScience 35:751-754.

Seemann, J.R. 1989. Light adaptation/acclimation of photosynthesis and the regulation of ribulose-1,5-bisphophate carboxylase activity in sun and shade plants. Plant Physiol. 91:379-386.

Smith, A.C. 1947. The families of the Illiciaceae and Schisandraceae. Sargentia 7:1-224.

Thayer, S.S. and O. Björkman. 1990. Leaf xanthophyll content and composition in sun and shade determined by HPLC. Photosyn. Res. 23:331-343.

Thompson, W.A., L.K. Huang, and P.E. Kriedemann. 1992. Photosynthetic response to light and nutrients in sun-tolerant and shade-tolerant rainforest trees. II. Leaf gas exchange and component processes of photosynthesis. Austral. J. Plant Physiol. 19:19-42.

White, D.A. and L.B. Thien. 1985. The pollination of Illicium parviflorum (Illiciaceae). J. Elisha Mitchell Scientific Soc. 10:15-18.

Xu, D-Q. and Y-K. Shen. 1999. Light stress: Photoinhibition of photosynthesis in plants under natural conditions, p. 483-497. In: M. Pessaraki (ed.). Handbook of plant and crop stress. 2nd ed. Marcel Dekker, New York. 